\title{
Analyzing Determinant Components on East Java Rice Surplus Contribution Using Dynamical System Approach
}

\author{
Kuntoro Boga Andri (Corresponding Author) \\ Assessment Institute for Agricultural Technology West Sulawesi, IAARD - Indonesia Ministery of \\ Agiculture. Jln. H. Abdul Malik Pattana Endeng, Mamuju, Sulawesi Barat 91512, Indonesia \\ Tel: +62-426-2321830 Fax: : +62-426-2321830 E-mail: kuntoro@litbang.pertanian.go.id
}

\section{Nugraha Pangarsa}

Balai Pengkajian Teknologi Pertanian Maluku Assessment Institute for Agricultural Technology East Java, IAARD-Indonesi Ministery of Agiculture. Jln. Raya Karangploso Km 4 PO Box 188, Malang, Jawa Timur 65101, Indonesia. Tel: +62-341-471255 E-mail: kuntoro@,litbang.pertanian.go.id

(Received: Jan 15, 2015; Reviewed: Nov 13, 2015; Accepted: Oct 19, 2016)

\begin{abstract}
The Ministry of Agriculture has proclaimed rice as a main food commodity, beside corn, soybeans, meat and sugar. In order to achieve the target of the Ministry of Agriculture, East Java provincial government has stipulated a policy, focusing on rice surplus of 5 million tons in 2014. This attempt is to reach the surplus number through a wide selection of technological innovations (determinant component) that increases the productivity of rice (New Superior Variety/VUB, Site Specific Nutrient Management/SSNM, Integreted Crop Management/PTT, Jarwo/double row planting system, balanced fertilization, SOP harvest / postharvest), as well as an increase in Planting Index/IP by improving irrigation and food diversification program. By using a dynamical system approach (modeling), it can be measured the contribution of each determinant components in achieving surplus / rice self-sufficiency through simulation. The results of the simulation, it was known that the East Java's rice surplus will continue to decline from 1,806,282 tons (2014) with 170\% self-sufficiency index, fell to 1.706.771 tons (2017) and would be 1.367.901 tons (2025). This condition is due to the increasing number of population, agricultural area continues to shrink and productivity is relatively fixed. Index sufficiency / surplus will increase if there is an interference of educational policy to implement a massive exceed of VUB, SSNM, PTT, Jarwo, balanced fertilization, SOP harvest / post-harvest, IP increasing and the succession of diversification in East Java. A surplus of 4.7 million tons of rice in 2014 within East Java can be achieved by implementing massive educational policy movement of PTT and VUB (100\% of the area), the application of SOP harvest / post-harvest to reach at least $50 \%$ of the area of paddy and controlling OPT strictly. The highest self-sufficiency index (281\%) and a surplus of 5.22 million tons will be achieved in case of an interference in implementing policy of PTT jarwo (100\% of the area) and an IP increasing amounted to 1.0 (additional areas that can be irrigated, $33.000 \mathrm{ha}$ ). Sustainable rice surplus would be achieved in case of an attempt to make food diversification program completely successful, strengthen family planning programs and strictly guard the Regulation No. 5/2012 on the minimum acreage of paddy fields that must be maintained.
\end{abstract}

Keywords: Dynamical system, causal loop, surplus, East Java 


\section{Introduction}

The Ministry of Agriculture proclaim that the rice, corn, soybeans, meat, milk and sugar as the five prominent food commodities. The targeted number of rice self-sufficiency is about 76.6 million tons of rice (10 million tons of rice surplus). Based on the data from the Central Statistics Agency (BPS 2011) until July 2011, Indonesian rice import has reached 1.57 million tons amounting to approximately 7.04 trillion rupiahs. The imports are primarily from Vietnam (892 thousand tons), Thailand (665.8 thousand tons), China (1.869 tons), India (1.146 tons), Pakistan (3.2 thousand tons), and some other countries (3.2 thousand tons). This condition requires Indonesian to recover food selfsufficiency issueandto comply with national rice necessity that proportionate to the high population growth of Indonesian within all region (Erwidodo et al., 1996; BKP-LPUI, 2002; Ariani and Ashari, 2003). Central statistics agency (BPS) calculates that the population growth rate in 2005 to 2010 is expected to reach $1.3 \%$, in 2011 to 2015 by $1.18 \%$ and $0.82 \%$ in 2025 to 2030 . While the National Development Planning Agency (BAPPENAS) estimates that by 2015 the population of Indonesia will reach approximately 243 million. Rice consumption per capita of Indonesia reaches $139 \mathrm{~kg}$ per year, consequently, 33.78 million tons of rice are needed. In 2030, rice necessity for foos will reach 59 million tons for the approximate total population 425 million people (Mulyana, 1998; Prabowo et al., 2012; Nugraha et al., 2007).

In order to profitably accomplish the target of the Ministry of Agriculture in rice self-sufficieny, East Java provincial government has promulgated a policy to accomplish 5 millions tons of rice surplus in 2014 ( $50 \%$ of the national target). The agricultural development policy decided and enacted by the central government / province to direct, encouragee, control and regulate the development to accomplish the objectives of agricultural development (Maxwell and Timothy, 1992; Simatupang, 2003; Departemen Pertanian, 2005).

It has been knownthat the attempts to achieve a rice surplus in East Java is obstructed by several things as follows: (1) The rate of popluation growth is increasing up to $0.76 \%$ per year, (2) The shrinking of land which the rate of land conversion is approximately $1 \%$ per year (+1.000 ha), (3) rice landform cannot be conducted by the farmers, (4) rice consumption per capita per year is about $100 \mathrm{~kg}$ (with a target of $91 \mathrm{~kg} /$ capita / year), (5) the condition of irrigation network (JITUT / JIDES ) and irrigation networks in 6 (six) region watersheds (DAS) in need to be repaired, (6) shrinkage results due to harvest and post-harvest remains high, (7) the drought / natural disasters and pests that recently is increading significantly, therefore significantly reduces the harvested area.

The current agricultural development, as well as forthcoming development, is directed to the development of systems and agribusiness which is competitive, populist, sustainable and decentralized. Karama (1999) suggests that programs which ever launched by the department of Agriculture basically have the goal to empower and increase farmer's independency. While Rusastra (2000) stated that relevant to the 
implementation of regional autonomy, thus the policy and the implementation of agricultural development will be more decentralized, with the problems and challenges which are more complex, therefore it requires a dynamic and flexible policy according to changes in the strategic environment (Asyawati, 2002; Muhammadi et al., 2001; Tasrif M, 2004)

Although the attempts to achieve rice surplus faces several obstacles, but there are opportunities to overcome these obstacles through the identification and implementation of rice surplus. Determinant component of rice surplus which is also an innovation technology are identified as the VUB (Inpari), SSNM, PTT, Jarwo row, balanced fertilization, SOP harvest / post-harvest. In addition the success of the diversification program and IP enhancement through an improved irrigation systems are also needed to be taken into account (the current IP 1.86). the long-term self-sufficiency has been considered by the East Java provincial government by issuing Local Regulation number 5/ 2012 to set a minimum area of agricultural land which required to be maintained.

To identify the contribution of each determinant component in achieving self-sufficiency / rice surplus, it has been designed an activity using a dynamic system approach (modeling). Modelling is compiled by identifying and arranging all of the barriers and opportunities in rice advancement (identified as variable / parameter) and to discover a causal relationship of the variables / parameters of the model compiler (Chechland, 1981; Richardson and Pugh, 1986; Suryani, 2006; Bloom, 2008).
The success of agricultural development is commonly followed by policy which are concerning the application of technology, the use of the means of production, commodities, prices of input-output and etc. Agricultural development policy enacted by the government concentrates to direct, encourage, control and regulate development in order to accomplish the objectives of agricultural development (Saad, 1999; Simatupang, 2003).

During the implementation of development, problems or obstacles are typical, yet it should be immediately identified and solved (Suyamto, 2000). In the manner that the attainment of rice self-sufficiency program, it requires a solution for improving rice production and reducing the dependence on rice imports to fulfill the internal demand. The problems related to the accomplishment of rice production need the modeling analysis system to determine the factors that either influence directly or indirectly the rice production. Modeling analysis can be taken as policy recommendations to encourage the attainment of rice self-sufficiency, particularly in East Java (Forrester, 1961; Sugianto et.al, 2002; Irawan. 2005; Pudjadi and Harisno. 2007)

This agricultural development policy analysis is adjustable, prompt in implementing and generating output, as for inputingto make a decision in the local region (Suyamto, 2000). The preceding years experience indicates that the results of the policy analysis is able to support the precision of agriculture activity within the local area (Suyamto, 2000). According to Rusastra (2000), the agricultural development policy analysis can 
be categorized into two conditions as follows: (1) Anticipatory policy analysis aims to evaluate the ongoing policy and anticipate the new policy, and (2) Responsive policy that essentially responds to the actual issues during the enactment of policy.

The first step of model development is to identify the system that aims to provide an overview of the studied systems. This model development is designedin the form of diagram input component (input) with the environment system which produces an output (output), both expected and unexpected output. The picture is as shown in Figure 1.

\section{Materials and Method}

The identification and problem-solving suggestions regarding the achievement of rice self-sufficiency in East Java uses dynamic system andcorrelateseveral factors that influence in rice production either directly or indirectly toward targets produc- tion of rice self-sufficiency within East Java in 2014. There are two approaches to obtain the information. The first is identifying the problem directly in the field and obtaining sources of the data or information from the subject or institution that associated with soy-agribusiness. The applied procedures in this study are:

1. Identifying the problem and supporting factors that either related directly or indirectly to the attainment of rice self-sufficiency through a review of the literature.

2. Identifying the problem through the implementation of RRA (Rapid Rural Appraisal) and further analysis through FGD activities (Focused Group Discussion).

3. Preparing problem-solving advice for policy makers by using dynamic systems and implementing simulation models.

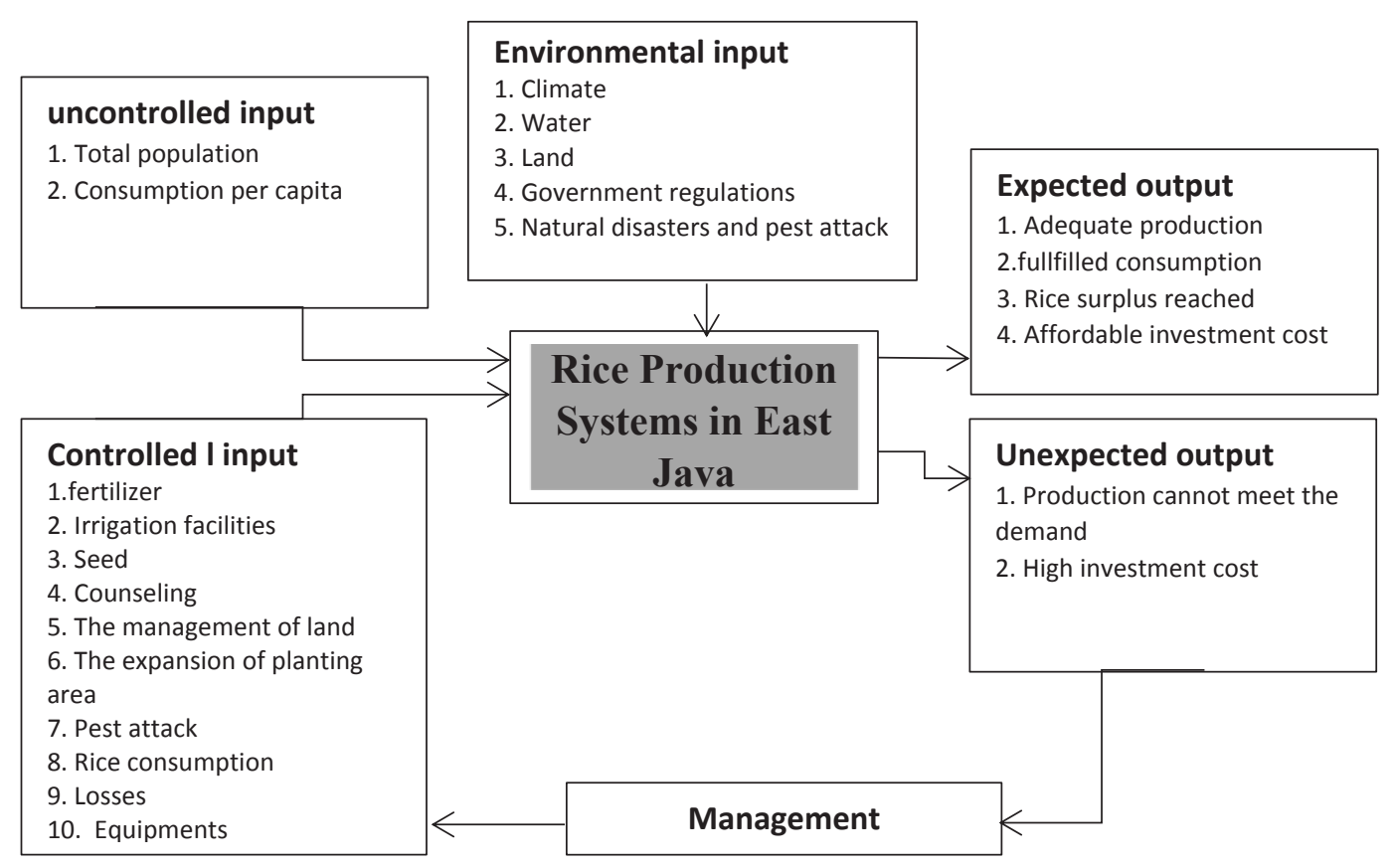

Figure 1. Input-Output Diagram of Paddy Production System 
4. Socializing a problem-solving advice and reporting to policy makers in East Java.

5. Conducting sustainablele evaluation based on the results of policy analysis in achieving rice self-sufficiency in East Java.

The study was conducting in January to December 2013. The data or information was collected by using secondary data that already occurred (reports from departments, agencies, and other related institutions) as well as the primary data. The primary data was collected through surveys and countryside understanding in a short time (Rapid Rural Appraisal) (Gibbs, 1985 In Surachman et al., 2012). After applying RRA, to learn more about the problem and the potential development of paddy, Focus Group Discussion (FGD) with farmers, extension workers, field workers and businesses at the provincial level was also conducted. During data collection, several information that are being collected are the condition of land use , irrigation, the use of seed, fertilization, pest control, population growth rate and production rate, shrinkage results, mechanization and also local policies related to rice production systems.

Data processing and analysis was done by the following procedure: (1) Preparing Causal loop diagrams which include consumption and production subsystems as well as the inclusion of environmental improvements issues, (2) Preparing stock and flow in Powersim Constructor Lite 2003 (3) Inputting variable data corresponding causal loop diagram into Powersim, 2003, (4) Conducting a test to the validation model. The process of validation model test starting from 2008 to 2011 which includes the total population, land area, harvested area and grain production, (5) Executing a sensitivity analysis and (6) Performing a simulation. This study used Powersim Constructor Lite 2003 to arranging the simulation. The result of the simulation is used to determine option related to the rice self-sufficiency policy (Shintasari, 1988; Widayani, 1999; Daalen and Thissen, 2001; Waskito, A.B. 2005)

\section{Results and Discussion}

\subsection{Model Arrangement}

All of the identification result of surplus obstacles and opportunities has been formulated in the form of causal loop diagram / CLD (Figure 2), through focus group discussions in which many stakeholders were involved. CLD is a diagram that illustrates the interaction between the parameters or variables in dynamic systems consisting of consumption and production subsystems. After CLD has been arranged, the next step is to collect the data or information in accordance with CLD components. Data collection through field observations and followed up by FGD for comprehending the data and information involving farmers, extension workers or officers and policy makers. Before the primary data collected, literature review has been carried out, particularly to obtain quantitative secondary data (Table 1).

Before conducting the simulation, it is necessary to validate the model to test the appropriateness of the developed model which is compatible with field circumstance. The validation of the model has been made for the total population, area and production 


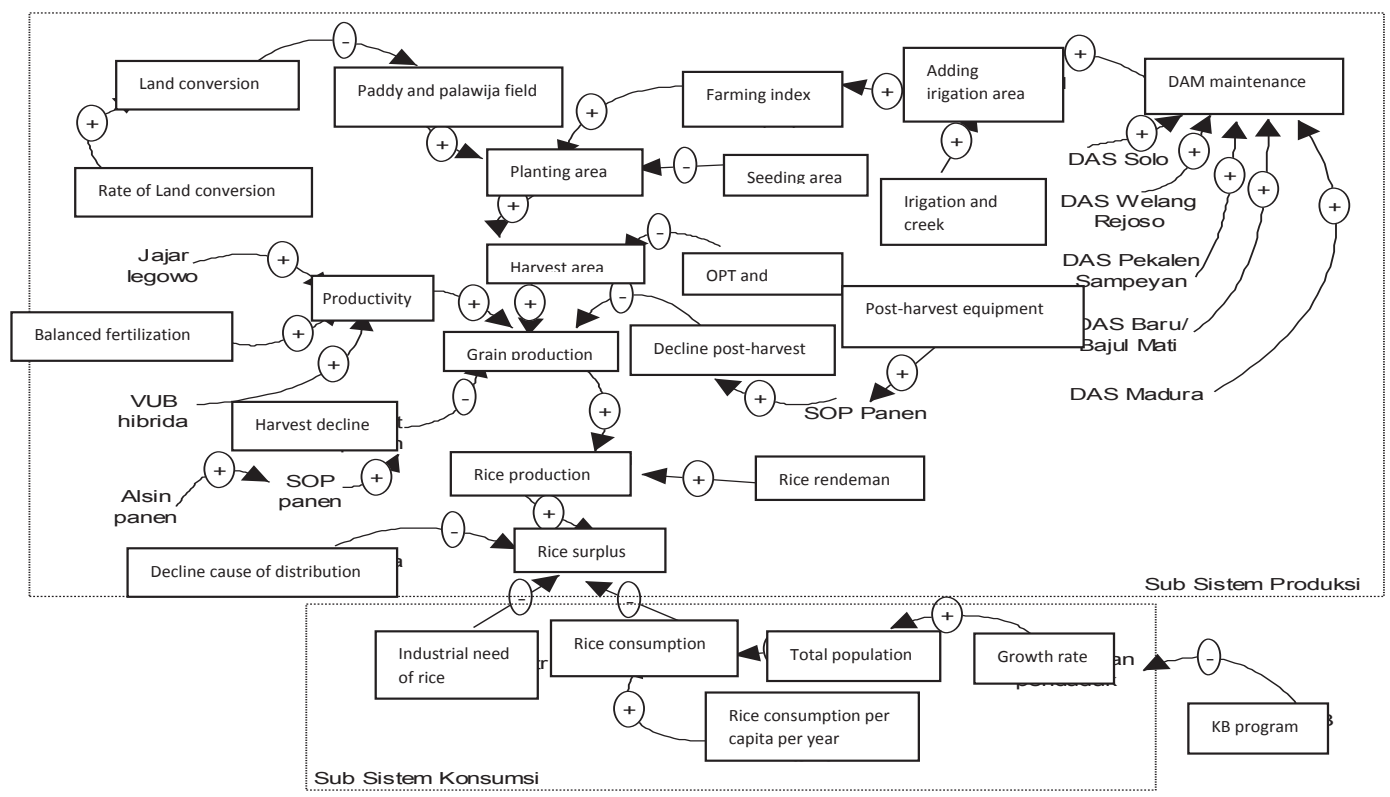

Figure 2. Causal Loop Diagram(CLD) East Java rice surplus

Table 1. The variables/parameters and values used

\begin{tabular}{|c|c|c|c|}
\hline No & Variable or Parameter & Value(s) & Data Source \\
\hline 1 & Total populations of the first (2008) calculation & $38,412,548$ & $\begin{array}{l}\text { Disnakertransduk } \\
\text { East-Java Province } 2012\end{array}$ \\
\hline 2 & Population growth per year & $0.75 \%$ & $\begin{array}{l}\text { Disnakertransduk } \\
\text { East-Java Province } 2012\end{array}$ \\
\hline 3 & Rice consumption per year per capita & 0.091 tons & BKP East-Java 2012 \\
\hline 4 & Rice field area for the initial calculation (2008) & $1,108,578$ ha & BPS East-Java 2012 \\
\hline 5 & Land conversion per year & $0.01 \%$ & $\begin{array}{l}\text { Historical Data BPS } \\
\text { East-Java 2008-2011 }\end{array}$ \\
\hline 6 & $\begin{array}{l}\text { If Perda No. } 5 / 2012 \text { enacted, the vast rice-field } \\
\text { minimal will be }\end{array}$ & 831,434 ha & DispertaProv 2013* \\
\hline 7 & Rice needs for industry & $\begin{array}{l}10 \% \text { from total } \\
\text { production }\end{array}$ & $\begin{array}{l}\text { Disperindag } \\
\text { Prov } 2010^{*}\end{array}$ \\
\hline 8 & Farming Index (FI) Rice & 1.86 & DispertaProv $2011 *$ \\
\hline 9 & $\begin{array}{l}\text { Reduction of planting area into a harvest area } \\
\text { (pest and drought) }\end{array}$ & $3 \%$ & $\begin{array}{l}\text { Historical data Disperta-Prov } \\
\text { 2008-2011 }\end{array}$ \\
\hline 10 & Rice productivity as the basis for calculation & 6.174 ton GKP & BPS Prov 2008 \\
\hline 11 & Land used for seed & 17,000 ha & BPSB East Java $2012 *$ \\
\hline 12 & Additional productivity application Jarwo row & 0.6 ton $/ \mathrm{ha}$ & BPTP East Java * \\
\hline 13 & $\begin{array}{l}\text { Additional productivity, the application of a } \\
\text { balanced fertilizer }\end{array}$ & 1.2 ton $/ \mathrm{ha}$ & BPTP East Java * \\
\hline 14 & VUB additional productivity application & 0.6 ton $/ \mathrm{ha}$ & BPTP East Java* \\
\hline 15 & Additional productivity application & 1.0 ton $/$ ha & \\
\hline 16 & Loss due to harvest & $3.9 \%$ & BB post-harvest 2007 \\
\hline 17 & Losses due to post harvest & $8.08 \%$ & BB post-harvest 2007 \\
\hline 18 & Conversion of GKP to DUP & $80.90 \%$ & Puslitbangtan 2012 \\
\hline 19 & Conversion of grain to rice & $66.60 \%$ & BPS East Java 2011 \\
\hline 20 & Loss due to the distribution of rice & $2.92 \%$ & BPS 2008 dan P2HP 2009 \\
\hline 21 & Improving irrigation (6 DAS) and JITUT/JIDES & $\begin{array}{l}33,200 \mathrm{ha}, \\
\text { increasing IP } \\
1.0\end{array}$ & Dinas PU irrigation, $2012 *$ \\
\hline
\end{tabular}

Descriptions:

Assumptions used:

(a) $\mathrm{KB} /$ Family Planing program is well-implemented, therefore the population growth rate is constant,

(b) Total Mechine equipments for planting, harvest and post-harvest was considered constant

* Data was obtained from the results of the consultation and FGD 
of paddy rice harvest began in 2008-2011 (4 years) with reference to the mean squre error (MSE) is less than 5\% (Appendix Figure 1). According to Suryani (2006), the model is already consistent with the real circumstance of the field, if MSE is $<5 \%$.

\subsection{Simulation Results}

The simulation results show that if intervention is not conducted (action program), then the East-Java rice surplus will be declined steadily from 2014 amounted to $1,806,282$ tons (with an index of $170 \%$ selfsufficiency), in 2017 to $1,706,771$ tons in 2025 amounted to 1,367,901 tons (Figure 3). This is due to the increasing number of population; according to the rate of land conversion, productivity is relatively fixed, while the area of land continues to decline. The measurement of the contribution of each determinant component of the surplus has been done through simulation with the results as shown in Table 2.

From the options above, the chosen policy interventions to accomplish a surplus of 5 million tons in 2014 is to conduct a massive extension in implementing PTT Jarwo and VUB (100\% of the total area), applying SOP harvest or post-harvest (min $50 \%$ of the total area) and promoting diversification programs (leading to $80 \mathrm{~kg} / \mathrm{cap} /$ year) and controlling pests attack strictly which recently the attack is considered high (No. 8, table 3). By performing these attempts, the surplus can be approximately achived 4.70 million tons (Figure 3 and Figure 4).

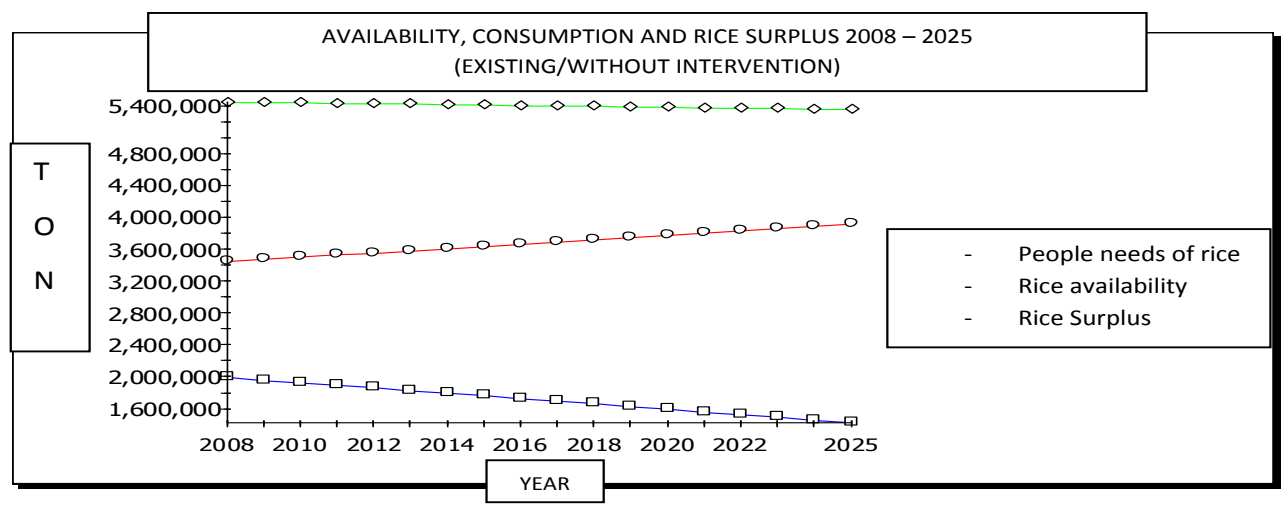

Figure 3. Supply, Consumption and Surplus Rice (2008-2025)

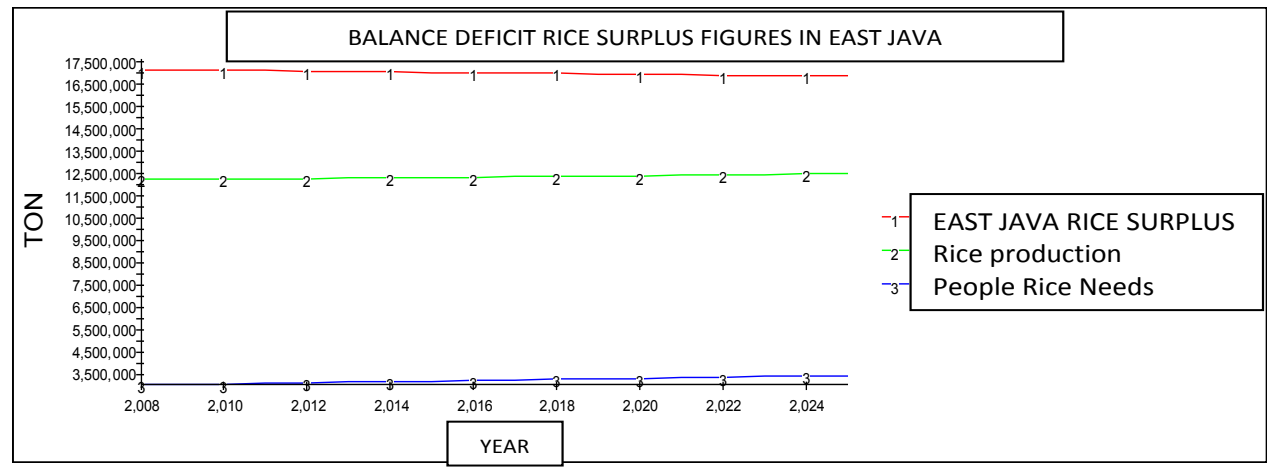

Figure 4. Rice surplus in EJ through intervention of application PTT Jarwo, VUB, SOP harvest /postharvest and diversification 
Table 2. Contributions from Each Component Makers on Self-Sufficiency (Surplus Rice) in EJ

\begin{tabular}{llccc}
\hline No & \multicolumn{1}{c}{ Determinant Component } & $\begin{array}{c}\text { Areal Scale } \\
\text { Application }\end{array}$ & $\begin{array}{c}\text { Rice Surplus } \\
\text { (ton) }\end{array}$ & $\begin{array}{c}\text { Self-Sufficiency } \\
\text { Index (\%) }\end{array}$ \\
\hline 1 & VUB Inpari & $100 \%$ & 2,27 million & 186 \\
2 & Jarwo row & $100 \%$ & 2,27 million & 186 \\
3 & PHSL & $100 \%$ & 2,62 million & 199 \\
4 & PTT Jarwo & $100 \%$ & 3,34 million & 221 \\
5 & Balanced fertilizer & $100 \%$ & 2,79 million & 204 \\
6 & Increasing Farming index (+ 1) & Expanding irrigation & 3,19 million & 216 \\
7 & Combination PTT and Farming Index & area 33,292 ha & 5,22 million & 281 \\
8 & PTT jarwo & $100 \%$ & & 281 \\
& Diversifycation & $100 \%$ & 4,70 million & \\
& VUB Inpari & $80 \mathrm{~kg} / \mathrm{cap} / \mathrm{th}$ & & \\
& SOP Harvest/Post-Harvest & $100 \%$ & & \\
\hline
\end{tabular}

Sustainable self-sufficiency will be achieved by conducting several things as folloes: (1) extending an area that can be irrigated (improvement of irrigation networks in 6 DAS and repair JITUT / JIDES) covering an area of 33,200 ha, (2) enhancing the productivity, (3) promoting food diversification program, (4) establishing the family planning program and strictly controlling the regulation No. 5/2012 on minimum acreage of paddy fields that must be maintained.

\section{Conclusion}

The conclusion that can be drawn from this study is the target of 5 million tons of rice surplus in East Java in 2014 will be accomplished by intervening PTT application, VUB, handling of harvest/post-harvest which reach all areas of rice and strictly conducting a pest control. In addition, the diversification of rice (rice consumption reduction of $10 \mathrm{~kg} / \mathrm{cap} /$ year) should be applied. Rice surplus target of 5.22 million tons more will be accomplished when the IP is plus $(+1), \mathrm{n}$ giving additional area of irrigated field about 33,200 ha and complete application of PTT $(100 \%$ of the total area).
The implications of policy relevant to the conclusions can be explained as follows: a) Short-term: In the short term implication, the compatible program to accomplish a surplus in rice are (1) SLPTT. In applying SLPTT the use of VUB, Jarwo row, pest strictly control, and the application of SOP harvest need to be taken into account seriously, (2) In addition, there should be a special program to reduce losses of post-harvest, (3) The program of diversification of rice must be intensified to accomplish a reduction in rice consumption of $10 \mathrm{~kg} / \mathrm{cap} / \mathrm{year}$, (4) For the district that still has productivity below 6.7 tons/ha, needs to be enhanced so that the productivity can reach at least 6.7 tons/ha. The application of SOP harvest or post-harvest will have implications for the use of machine equipment; b) Long-term; Sustainable rice self-sufficiency can be accomplished by extending the irrigated areal (improvement of irrigation networks in 6 DAS and repair JITUT / JIDES) covering an area of 33,200 ha, enhancing the productivity, promoting food diversification program, establishing the family planning program and controlling regulation No. 5/2012 on the 
minimum acreage of paddy fields that must be maintained.

\section{References}

Anonymous, (2001). Analisis kebijaksanaan Pembangunan Pertanian di BPTP Karangploso. Makalah Lokakarya Peningkatan kapasitas Analisis Kebijaksanaan Pembangunan Pertanian. Bogor 7 Juni 2001.

Anonymous, (2002). Analisis dan Penanggulangan Masalah Pembangunan Pertanian di Jawa Timur. Laporan Penelitian.

Anonymous, (2011). Jumlah Penduduk Jawa Timur. Dinas Tenaga Kerja Transmigrasi dan Tenaga Kerja Provinsi Jawa Timur

Ariani, M. and Ashari. (2003). Dinamika Konsumsi Beras Rumah Tangga dan Kaitannya dengan Diversifikasi Konsumsi Pangan oleh Ekonomi Padi dan Beras Indonesia. Jakarta: Badan Penelitian dan Pengembangan Pertanian, Departemen Pertanian.

Asyawati, Y. (2002). "Pendekatan Sistem Dinamik dalam Penataan Ruang Wilayah Pesisir (Studi Kasus Wilayah Pesisir Kabupaten Bantul, Provinsi DIY)" (tesis). Bogor: Institut Pertanian Bogor.

BKP-LPUI (Badan Ketahanan Pangan-Lembaga Penelitian UI). (2002). Analisis Skenario Pemenuhan Kebutuhan Pangan Nasional Hingga Tahun 2015. Ditinjau dari Aspek Sosial Kelembagaan dan Pedesaan. Jakarta: Departemen Pertanian.

Bloom, J. (2008). Systems Thinking and Complex-Transferrable. Learning in
Education for Sustainability. Department of Teaching \& Learning College of Education Northern Arizona University Prepared for The Education Sustainability Infusion Project of The Coconino Country Sustainable Economic Development Initiative (SEDI)

BPS Provinsi Jawa Timur, (2008-2011), Jawa Timur Dalam Angka. Biro Pusat Statistik Provinsi Jawa Timur.

BPS, (1996). Survei susut pascapanen MT 1994/95 dan MT 1995. Kerjasama BPS, Ditjen Tanaman Pangan, Badan Pengendalian Bimas, Bulog-Bappenas, IPB dan Badan Litbang Pertanian. Biro Pusat Statistik.

Chechland, P. B. (1981). System Thinking, Systems Practices. Wiley Chichester. p.120-131.

Coyle, R.G. (1996). System Dynamics Modelling: A Practical Approach. Chapman \& Hall/CRC. p.65-67

Daalen, V., and W.A.H. Thissen. (2001). Dynamics Systems Modelling Continous Models. Delft: Faculteit Techniek, Bestuur en Management (TBM). p.35. Departemen Pertanian. (2005). Prospek dan Arah Pengembangan Agribisnis Padi. Jakarta.

Erwidodo, T. Sudaryanto, A. Purwono, M. Ariani and K. S Endraningsih. (1996). Telaahan Trend Konsumsi Beras di Indonesia. Kerjasama Pusat Penelitian Sosial Ekonomi Pertanian dengan Proyek DPG Pusat. Bogor: Departemen Pertanian. p.31.

Forrester, J.W. (1961). System Dynamics: The foundation Under System Thinking. Sloan School of Manage- 
ment MIT. Cambridge, MA 02139.

URL: $\quad \mathrm{ftp}: / /$ sysdin.mit.edu/ftp/sdep/ papers/D-4828.html pada tanggal 12 Maret 2012. Gardner, B. 1987. The Economics of Agricultural Policies. Macmillan Publishing Company. New York. USA. p. 45-56

Irawan. (2005). Analisis Ketersediaan Beras Nasional : Suatu Kajian Simulasi Pendekatan Sistem Dinamis. Prosiding Multifungsi Pertanian dan Ketahanan Pangan. Pusat Penelitian Tanah dan Agroklimat Bogor. Indonesia.

Karama, S. (1999). Paradigma Baru Pembangunan Pertanian. Makalah Rapat Kerja Badan Litbang Pertanian di Bogor, 4 Maret 1999.

Kementan. (2011). Rencana Strategis Kementerian Pertanian Tahun 2010-2014. Edisi Revisi. Kementan, Jakarta.

Maxwell, S. and R. F. Timothy. (1992). Houshold Food Security: Concepts, Indicators, Reasurements, A Technical Review. Rome: International Fund for Agriculture Development.

Muhammadi, E. Aminullah and B. Soesilo. (2001). Analisis Sistem Dinamis : Lingkungan Hidup Sosial, Ekonomi, Manajemen. Jakarta: UMJ Press.

Mulyana, A. (1998). "Keragaan Penawaran dan Permintaan Beras Indonesia dan Prospek Swasembada Menuju Era Perdagangan Bebas Suatu Analisis Simulasi" (Dissertation). Bogor: Institut Pertanian Bogor.

Nugraha, S., R Thahir and Sudaryono, (2007). Keragaan Kehilangan Hasil Pasca Panen Padi di 3 Agroekosistem. Balai Besar Penelitian dan Pengem- bangan Pasca Panen Pertanian, Badan Penelitian dan Pengembangan Pertanian

Prabowo, A., Hermanto, Y. Nugraha, A. Somantri, Nurjaman and Z. Susanti. (2012). Pencapaian surplus 10 juta ton beras pada tahun 2014 dengan pendekatan dinamika sistem (System Dynamics). Workshop Nasional. Pengembangan Kebijakan Pertanian Mendukung Pencapaian Target Suskses kementan 2014 Melalui Aplikasi Siystem Modellling. Jakarta, 14 Juli 2012. 22p. Pudjadi, T. and Harisno. (2007). Model Pengelolaan Stok dan Konsumsi Beras Berbasis DSS pada Era Otonomi Daerah (OTDA). URL: http://journal uii.ac.id/index.php/Snati/article/ view/1675 pada tanggal 20 Januari 2015. Rachman, H. P. 2001. "Kajian Pola Konsumsi dan Permintaan Pangan di Kawasan Timur Indonesia" (Dissertation). Bogor: Institut Pertanian Bogor.

Richardson, G.P. and A.L. Pugh. (1986). Introduction to System Dynamics Modelling with Dynamo. The MIT Press, Cambridge, Massachussete, and London, England.

Rusastra. I.W. (2000). Operasionalisasi dan Perumusan Analisis Kebijaksanaan Sosial Ekonomi Pembangunan Pertanian. Makalah disampaikan dalam lokakarya Analisis Kebijaksanaan Lingkup Badan Litbang Pertanian. 7 Juni 2001.

Saad, M. B. (1999). Food Security for The Food Insecure; New Challengers and Renewed Commitment. Centre for De- 
velopment Studies, University College Dublin, Ireland.

Shintasari, I. (1988). "Dinamika Persediaan Daging Sapi: Suatu Model Dinamik untuk DKI Jakarta” (skripsi). Bogor: Institut Pertanian Bogor.

Simatupang. P. (2003). Analisis Kebijakan Konsep Dasar dan Prosedur Pelaksanaan.Analisis Kebijakan Pertanian. Pusat Penelitian dan Pengembangan Sosial Ekonomi Pertanain. 1 (1): 14 35 .

Sugianto, Tjahyadi, Pantjar Simatupang, Moeljarno Djojomartono. (2002). Faktor-faktor Yang Mempengaruhi dan Sistem Pengendalian Stok Beras di Mayarakat. Jakarta: Badan Pusat Statistik.

Suryani, E., (2006). Pemodelan dan Simulasi. Graha Ilmu. Yogyakarta.

Suyamto, H. (2000). Hasil Pengkajian analisis masalah pembangunan pertanian di Jawa Timur. Dalam Soetjipto. Prosiding Seminar Hasil Penelitian/Pengkajian Teknologi Pertanian Mendukung Ketahanan Pangan Berwawasan Agribisnis. 588 - 595

Tasrif, M. (2004). Model Simulasi untuk Analisis Kebijakan: Pendekatan Metodologi Sistem Dinamik. Kelompok Penelitian dan Pengembangan Energi. Bandung: Institut Teknologi Bandung. Waskito, A.B. (2005). "Pemodelan Ekonometrik dan Dinamika Sistem Daya Saing Ekspor Komoditas Agroindustri Karet Alam Indonesia" (skripsi). Bogor: Institut Pertanian Bogor.

Widayani, K. (1999). “Analisis Perencanaan Kebijakan pengembangan Produksi Buah-buahan di Indonesia dengan Pendekatan Sistem Dinamik (Studi Kasus Pengembangan Produksi Mangga di Jawa Barat)" (Thesis). Bandung: Institut Teknologi Bandung. 